\title{
THE RIGHT OF A FEDERAL JUDGE TO COMMENT ON THE EVIDENCE
}

A trial judge's charge in the federal court called the jury's attention to the fact that the defendant had wiped his hands during the testimony and stated, "It is rather a curious thing, but that is almost always an indication of lying. Why it should be so, we don't know, but that is the fact. I think that every single word that man said, except when he agreed with the government's testimony, was a lie."

Defendant was convicted of violating the Narcotic Act, and the conviction was affirmed by the Circuit Court of Appeals. The Supreme Court reversed the decision, holding that the trial judge's charge was prejudicial error and that it added to the evidence. ${ }^{\mathrm{I}}$

In England ${ }^{2}$ and in our Federal Courts 3 it has long been recognized that, in charging the jury, the trial judge is not limited to instructions of an abstract sort. It is within his province whenever he thinks it necessary to assist the jury in arriving at just conclusions by expressing his opinion upon the evidence, provided he separates the law from the facts and makes clear to the jury that his opinion as to the facts is merely advisory, and that they are free to exercise their independent judgment and may totally disregard his opinion. Sir Mathew Hale thus described the function of the trial judge at common law:

Herein he is able in matters of law emerging upon the evidence, to direct them; and also, in matters of fact to give them a great light and assistance by his weighing the evidence before them, and observing where the question and knot of the business lies, and by showing them his opinion even in matter of fact; which is a great advantage and light to laymen.4

This rule prevails in the courts of some of the eastern states, ${ }^{5}$ but in most of the states the privilege has been denied by statute.

In charging the jury, the trial judge, not being limited to instructions of an abstract sort, can express his opinion in strong terms. ${ }^{6}$ The privilege of com-

${ }^{2}$ Quercia v. United States, 53 Sup. Ct. 698 (I933), reversing 62 F. (2d) 746 (C.C.A. Ist 1933).

2 Belcher v. Prittie, 4 Moore and Scott 295, 3 L.J.C. 85 (I834); Foster v. Steele, 5 Scott 28 , 6 L.J.C. 265 (1833); Davidson v. Stanley, 2 Mann. and G. 72I, 3 Scott (NR) 49 (I841).

3 Carver v. Jackson, 29 U.S. I, 7 L.Ed. 76r (I830); Magiac v. Thompson, 7 Pet. 348, 8 L.Ed. 709 (I833); Vicksburg and Meridian R. R. Co. v. Putnam, II 8 U.S. 545, 7 Sup. Ct. I, 30 L.Ed. r16r (I886); Herron v. Southern Pacific Co., 283 U.S. 95, 5I Sup. Ct. 383 , 75 L. Ed. 857 (1930).

4 Hale, History of the Common Law (I793) 291, 292.

5 Houghton v. City of New Haven, 79 Conn. 659, 66 Atl. 509 (1907); Mansfield v. Corbin, ${ }_{4}$ Cush. 213 (Mass. I849); Ware v. Ware, 8 Me. 59 (1831); Flanders v. Colby, 28 N.H. 34,39 (1853); State v. Hummer, 73 N.J.L. 714, 65 Atl. 249 (Igo6); Hurlburt v. Hurlburt, I28 N.Y. 420, 28 N.E. 651 (I89r); Ditmar v. Com., 47 Pa. St. 335 (1864); Rowell v. Fuller's Estate 59 Vt. 688, 10 Atl. 853 (1887).

${ }^{6}$ Lovejoy v. United States, 128 U.S. 17 I, 9 Sup. Ct. 57, 32 L. Ed. 389 (r888). " - I think you may have some difficulty in finding that it was a forgery."

Simmons v. United States, 142 U.S. I48, x2 Sup. Ct. I7r, 35 L. Ed. 968 ( 189 I). The judge 
menting on the evidence, however, has its limitations inherent in and implied from the very nature of the judicial office. The comments should not be in the nature of an argument; rather they should be a fair and dispassionate statement of what the evidence showed and a tempered expression of his opinion as to the facts. ${ }^{7}$ To assume the rôle of an advocate rather than an impartial judge is error as established by repeated decisions. ${ }^{8}$ The judge, however has been permitted to stress "the importance of the case because of the letting "down of the bars' protecting property rights and the lowering of the standards of honesty"9 provided that the duty of law enforcement was coupled with the duty of seeing that no innocent man was convicted.

It is important that hostile comment of the judge should not render vain the privilege of the accused to testify in his own behalf. ${ }^{\text {xo }}$ The court cannot use such language in his charge to the jury that he leaves with them the impression that they will be held up to ridicule, or be deceived if they render a verdict contrary to the views expressed in the charge. ${ }^{\text {Ix }}$

The comments upon the evidence must be limited to facts which have actually been brought out by evidence in the case and not to a conjectural state of facts of which no evidence has been offered..$^{\mathrm{x} 2}$ The Supreme Court seemed to believe the principal case fell within this objection, the trial judge having added to the evidence by commenting upon the defendant's demeanor while testifying.

This view of the court would infer that the defendant's demeanor while on the stand was not evidence. The authorities contradict any such inference. The cases uniformly sanction the proposition that the jury may properly take into consideration the demeanor of the witness in determining his credibility. ${ }^{13}$ If the

refused jury's request to be discharged on failing to agree saying that he regarded the testimony as convincing.

Dillon v. United States, 279 Fed. 639 (C.C.A. 2d r92I). " . . . . the court's opinion is that the defendant is guilty of the crime charged."

United States v. Philadelphia and Reading Rd. Co., I23 U.S. II3, 8 Sup. Ct. 77, 3 I. Ed. I38 ( 1887 ). "In other words, while the court does not desire to control your finding, but submits the question to you, it is of the opinion that you should not, under the circumstances, find for the plaintiff."

7 Hickory v. United States, I60 U.S. 408, I6 Sup. Ct. 327,38 L. Ed. 474 (I896).

${ }^{8}$ Weare v. United States, I F. (2d) 6I7 (C.C.A. 8th I924); O'Shaughnessy v. United States, I7 F. (2d) 225 (C.C.A. $5^{\text {th }}$ I927); Sunderland v. United States, rg F. (2d) 202 (C.C.A. 8th 1927); Hunter v. United States, 62 F. (2d) 217 (C.C.A. 5th r932).

9 United States v. Freedman, 268 Fed. 655 (D.C.E.D. Pa. 1920).

ro Hickory v. United States, supra, note 7 ; O'Shaughnessy v. United States, supra, note 7; Malaga v. United States, 57 F. (2d) 822 (C.C.A. Ist I932).

Ir Rudd v. United States, I 73 Fed. 9I2 (C.C.A. 8th I909); Carney v. United States, 295 Fed. 606 (C.C.A. 9th I924).

12 United States v. Breitling, 20 How. 252 (U.S. I857); Mullen v. United States, I06 Fed. 892 (C.C.A. 6th Igor).

${ }_{13}$ "The witness present, the promptness and unpremeditatedness of his answers or the reverse, their distinctness and particularity or the want of these essentials, their incorrectness in 
jury may consider the demeanor of the witness, it would seem to be a variety of real evidence and to be the proper subject of comment by the judge. If the judge added to the evidence it was by his statement that certain behavior was nearly always an indication of lying. The significance of nervous behavior is a matter of experience as to which the jury should have been left free to form their own judgment. The positive and unqualified statement by the judge apparently foreclosed the matter. ${ }^{{ }^{14}}$

Since the witness's demeanor upon the stand is to be observed and taken into consideration by the jury it is a part of the evidence, and so it is within the province of the trial judge to comment upon this particular evidence as well as any other type of evidence and subject only to the same limitations. For these reasons it seems the Supreme Court stated the rule too broadly and the trial judge's comment did not add to the evidence, though it may have exceeded the bounds of fair comment in being highly prejudicial.

\section{LAWRENCE WolfF Gidwitz}

\section{ANALYSIS OF "APPARENT AUTHORITY" IN PRINCIPAL AND AGENT}

In the recent case of Berryhill v. Ellett ${ }^{\mathrm{x}}$ plaintiff bought a policy from the defendant insurance company through Ellett, the district agent. The policy stated that the district agent should collect only the first premium, the other premiums being payable only at the home office or to an "authorized" agent upon delivery of a receipt signed in a specified way. Despite the fact the general agent had refused upon plaintiff's request to allow a discount on premiums paid in advance, plaintiff nevertheless began paying his premiums in advance to Ellett. The latter allowed plaintiff discounts on the I927, I930, and I93I premiums, which were not paid directly to the specified agents of the company as required by the wording of the policy. The general agent and the home office had no knowledge of these transactions. When Ellett was unable to perform his agreement with plaintiff by paying the premiums to the company as they fell due, the plaintiff brought an action against the company, the general agent, and Ellett, alleging "that the insurance company ... . by their acts, conduct, and

generals or particulars, their directness or evasiveness, are soon detected . . . The appearance and manner, the voice, the gestures, the readiness and promptness of the answers, the evasions, the reluctance, the silence, the contumacious silence, the contradictions, the explanations, the intelligence or the want of intelligence of the witness, the passions which move or control-fear, love, hate, envy, or revenge - are all open to observation, noted, and weighed by the jury." Chief Justice Appleton, Evidence (I860), 220.

"There is, however, a secondary advantage to be obtained by the personal appearance of the witness; the judge and the jury are enabled to obtain the elusive incommunicable evidence of a witness' deportment while testifying, and a certain subjective moral effect is produced upon the witness." 3 Wigmore, Evidence (2nd ed. 1923), \& 1395, 96.
14 Allis v. Leonard, 58 N.Y. 288 (1874).
I 64 F. (2d) 253 (1933). 